\title{
Ethical issues in health research in children
}

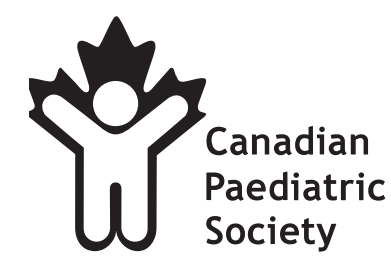

Français en page 714

\begin{abstract}
Health research is a moral duty because it is the foundation for evidence-based care by all health care practitioners. Specific Canadian policies and regulations govern the conduct of human research; ethics review of research is required before research is conducted. Research in children poses important challenges with regard to informed consent and assent, vulnerability and potential conflicts of interest (COI). Paediatric health researchers should advocate for research participation by children, while being attentive to mitigating risks.
\end{abstract}

\section{Key Words: Children; Ethics; Research}

\section{OBJECTIVES}

The objectives of the present statement are to:

- provide the ethical rationale as to why the conduct of research in children is a moral duty;

- outline the regulations governing research in Canada;

- outline the roles and responsibilities of the research ethics board (REB);

- review issues of consent and assent by children;

- describe potential COI for researchers conducting research in children;

- describe the obligation to offer to return a summary of research results and, when relevant, individual results to participants; and

- describe children who are exceptionally vulnerable and identify safeguards for these populations (eg, those needing emergency care, those who are incarcerated, those participating in early phase drug research studies and those children in international health research settings).

\section{BACKGROUND}

Research in children is recognized as a moral duty based on several ethical principles $(1,2)$. These principles include distributive justice in making high-quality health care available to all populations, including vulnerable ones; beneficence in providing evidence-based care and nonmaleficence in avoiding harmful therapies, adopted either without evidence or extrapolated from experience with adults. These and other principles (Table 1) are key considerations in discussing ethical research in children. Encouraging excellent, informative research in children supports these principles and will lead to improved child health. Paediatric health care providers should also be aware of the need to advocate for the inclusion of women in research who are pregnant or breastfeeding to ensure the safety of the child. The message that underpins all these areas is that children may be harmed if health care providers do not provide care based on the best available evidence.

Children, as a population, have traditionally been underserved in research for a variety of reasons, including a protectionist attitude of some individuals, difficulties in recruiting adequate numbers for rare diseases, and financial disincentives related to the cost of bringing to market new drugs or new drug indications for a relatively small population (2-4). This is also reflected in a disproportionately low allocation of major granting agency funds to the paediatric research portfolio (eg, the United States National Institutes of Health allocated $11 \%$ of funds in 2004) (5).

Orphan drug legislation in many countries has attempted to expand indications for drugs for rare conditions (including most paediatric conditions) by providing incentives to pharmaceutical companies, such as regulatory fee waivers; tax credits; clinical research grants for drugs, devices and medical foods; protocol assistance; expedited review and market exclusivity (6). How well these incentives translate into direct benefits without increasing risk for children is unclear, and researchers should be attentive to only participating in trials that advance the health of children, and not just serve as marketing tools (7).

Additional contributors to the lack of child-focused research include more limited funding sources and fewer researchers examining paediatric issues. Support for government incentives and other mechanisms to increase research aimed at producing useful results that can translate into safer, clinically important products and information and, thus, better paediatric care should be strongly considered by members of the Canadian Paediatric Society.

\section{REGULATIONS GOVERNING RESEARCH IN HUMANS IN CANADA}

The guiding document in Canada for the ethical conduct of human research is the Tri-Council Policy Statement 


\section{TABLE 1}

Ethical principles impacting research in children

\begin{tabular}{lc}
\hline Beneficence & $\begin{array}{c}\text { Applying evidence-based care generated from } \\
\text { research specific to children }\end{array}$ \\
Nonmaleficence & $\begin{array}{c}\text { Avoiding harmful therapies extrapolated from } \\
\text { adult patient data or experience }\end{array}$ \\
Distributive justice & $\begin{array}{c}\text { Allowing research benefits to be available to } \\
\text { all populations }\end{array}$ \\
$\begin{array}{l}\text { Respect for informed } \\
\text { consent }\end{array}$ & $\begin{array}{c}\text { Supporting developing autonomy in children } \\
\text { considering research participation } \\
\text { Respect for privacy }\end{array}$ \\
\hline
\end{tabular}

(TCPS) (8). All human research in Canada must adhere to these guidelines and must undergo REB review where indicated, whether in public institutions (generally academic or health care establishments) or private practice.

All research conducted within institutions funded by the Canadian Institutes of Health Research, Natural Sciences and Engineering Research Council, and Social Sciences and Humanities Research Council (regardless of whether these organizations fund the specific research project) must follow the TCPS as a condition of funding. Additional guidance is available through the Declaration of Helsinki, the Council for International Organizations of Medical Sciences and the International Conference on Harmonization - Good Clinical Practice guidelines, of which Canada is a signatory $(9,10)$. Individual jurisdictions may have additional laws and regulations. For example, Quebec has legislation governing research in humans, with a specific article addressing research in children (11).

In addition to satisfying the needs of granting agencies and institutions, research ethics review and approved consent procedures are increasingly being required, along with disclosure of potential COI, to have research accepted for publication in peer-reviewed journals.

The TCPS requires an assessment of the degree of risk involved in a research proposal and the steps that have been taken to minimize that risk. It calls for increased scrutiny of research that poses more than a minimal risk, in both the magnitude of possible harms and the likelihood of occurrence. These tenets are echoed in the United States and other international jurisdictions in which risk assessment and the prospect of direct individual benefit is key for REBs in determining the approval of research in children (12).

A means of assessing research with respect to the relative risk of harm and benefit is through component analysis (13). Component analysis distinguishes risks that are associated with therapeutic risks (and the prospect of direct benefit to the child) from nontherapeutic risks (wherein procedures are undertaken solely to satisfy the needs of the research question). Allowable risk in therapeutic procedures is commensurate with the prospect of direct benefit. Because no such benefit is expected in nontherapeutic research, the TCPS restricts nontherapeutic research risk in children to that no greater than those encountered by persons in everyday life that relate to the research. There remains considerable debate as to how minimal risk is precisely defined; researchers should be aware of the broad scope of risks posed in research, including physical, emotional, psychosocial, judiciary or financial risks.

\section{ROLE OF THE REB}

The REB (similar to an institutional review board or a human investigations committee in other jurisdictions) is constituted of a multidisciplinary panel of scientific peers, experts in bioethics and law, and representatives of the lay community. It has a mandate to uphold the tenets espoused in the TCPS, which focus on the principle of respect for human dignity. These tenets include free and informed consent, respect for privacy and confidentiality, respect for justice and inclusiveness, and respect for vulnerable persons. Children may be particularly vulnerable and require special considerations in the design and conduct of the research.

As part of its mandate, the REB has the provision of a balanced review of the scholarly nature of the research (14). This scientific review recognizes that poorly conducted research is in itself potentially harmful because it exposes participants to procedures that will not provide reliable or valid knowledge and also wastes resources. The review may be performed by the REB, an ad hoc external expert or a separate scientific review committee. The REB also has a role, as does the investigator, in ensuring that the researcher has adequate control over the data generated from the research and the academic freedom to publish it.

The TCPS stipulates that the REB will give proportional review to research either in an expedited manner, when the risks are minimal, or via a full board review, when the risks are anticipated to be more than minimal. Expedited reviews may not be allowable by legislation in all jurisdictions (eg, Quebec). The REB is charged with an analysis of the distribution of potential harms and benefits applied in a proportionate manner to the degree of risk. As part of its deliberations, the REB will examine whether there is clinical equipoise (true uncertainty as to the most appropriate therapy) for randomized, controlled trials.

Paediatric health researchers should consider participating as members of their institutional REB. It is essential to support the peer-review work of the board; the process is educational from the standpoint of both science and bioethics, and there is opportunity to contribute to the evolution of the challenging ethical issues that currently face paediatric researchers $(15,16)$. Paediatric representation on an REB is particularly important in settings in which expertise relevant to children is lacking.

\section{CONSENT AND ASSENT TO PARTICIPATION IN RESEARCH}

Respect for persons includes respect for autonomous decision-making. It requires attention to the three main elements of informed consent - adequate information, voluntariness and capacity to understand the information (17). 
Responsibility for consent for participation in research by children who are unable to provide full consent themselves is vested in parents or guardians, who are assumed to have the best interests of the child in mind. Children, however, may develop an ability to fully consent during the course of a study or be able to consent to some aspects of the research.

While children are potentially compromised in each of the elements of informed consent, it is important to acknowledge that they live in an evolving context that may assist or hinder capacity by virtue of their illness and experience. Factors that may influence the adequacy of consent include information that is too complex or overwhelming in volume, parental or familial pressures that may curb voluntariness; and capacity, in part, related to neurocognitive development $(18-20)$. The socioeconomic and multicultural context and language of the population under study must also be considered in ensuring confidence that all elements of informed consent are met. The complexity and severity of potential outcomes of a study should also be considered in assessing whether a child has the capacity to understand the consequences of participation in a study (21).

There is evidence that consent for research by adults for themselves is often flawed, with poor understanding of the voluntary nature of participation, the meaning of randomization and other issues $(22,23)$. These flaws also apply to substitute decision-making by parents for their child. Decision-making may be clouded by emotional distress and medical acuity, dependent relationships when clinicians assume a dual role as researchers, and the interdependent nature of parent and child. Some studies have identified factors that enhance parental understanding. For example, in paediatric oncology research, involvement of nursing support, encouragement of questions and the use of audiovisual aids have been effective (24-26). It is important that a critical view be taken of the consent documents that support and document the process of consent to ensure that they are not overly long or complex.

Assent is the concept of providing agreement to participation in research where full consent is not possible by virtue of compromise of one of the three main elements of consent described above $(19,27,28)$. It is recommended that assent be sought for participation in research at an ageappropriate level, and as suitable to the complexity of the project under consideration. Children should be involved in the decision to take part in research as their developmental capacity dictates. Clearly, as the complexities and consequences of a research study increases, the need for more sophisticated reasoning and understanding of consequences will also need to increase for a child to provide full consent.

Very little empirical research has been completed on assent to research in children. This is especially true with respect to under what circumstances REBs determine whether assent is required; how researchers solicit children's assent; what children comprehend in various types of research; and what predicts successful assent procedures (29). Evidence $(20,27,30-32)$ suggests that the capacity to provide meaningful consent matures beyond 14 years of age but is
TABLE 2

\section{Potential conflicts of interest (COI) that may be encountered in research}

\begin{tabular}{ll}
\hline Type of COI & Examples \\
\hline Financial & $\begin{array}{r}\text { Employment or leadership position in commercial firm, } \\
\text { employment as consultant for commercial firm, stock } \\
\text { ownership, honoraria, research funding or grant } \\
\text { support, expert testimony, patents or other } \\
\text { renumeration, family member investments }\end{array}$ \\
Academic & $\begin{array}{l}\text { Promotion or tenure based on productivity, stature based } \\
\text { on publication impact scores, agenda of academic in } \\
\text { conflict with research agenda of potential } \\
\text { donors or sponsors } \\
\text { Research results supporting an ideology or preconceived } \\
\text { conclusions, recruitment of own patients to research } \\
\text { (duty of care) }\end{array}$ \\
\hline
\end{tabular}

very limited before nine years of age. This points to a group of nine- to 14-year-olds who will be in transition - some fully able to provide consent and some unable, despite their physical advances in maturity $(27,29)$. Paediatric health researchers must be particularly cautious in assessing assent and consent issues in this middle age range group, and in those with permanently diminished capacity, for example, children with serious developmental delay.

Dissent (the voicing of a desire not to take part in research) should be respected. Fully developed articulation of the reasons for dissent should not be required to end a child's participation in research. On the other hand, reasons for dissent should be explored to determine their validity. Parents are frequently best suited to assist in what would make the child more comfortable or in determining whether the research should continue. Researchers should also be cognizant of this dynamic and withdraw a child from the study if dissent is valid.

While a challenging area, respect for persons behooves paediatric health researchers involved in the recruitment of children for research to provide information that is accessible and appropriate for children, to solicit valid consent or assent, and to be proactive in the ongoing assessment of the continuing validation of a child's or the parents' agreement to participate in research $(33,34)$.

\section{COI AND COERCION}

COI has classically been thought of as being rooted in financial gains, but is increasingly recognized to encompass a very broad scope of issues, including personal academic gain or stature within the community (Table 2) (35). There is also potential for institutional $\mathrm{COI}$ in allowing pharmaceutical industries to drive the academic agenda of the institution (36).

It is important to recognize that COI is simply a description of the context of the researcher. It is not in itself a judgment of character or intent. However, how the COI is handled is crucial to fair disclosure. Researchers must entirely avoid some categories of COI that seriously undermine the confidence in the published work. Other COI require only disclosure, so that the public may judge the 
potential bias inherent in the situation. Clinical research trial groups and academic institutions increasingly have specific guidelines regarding COI that researchers are obligated to follow $(16,37,38)$. The majority of human research journals and scientific meetings now require some degree of COI disclosure in accepting a manuscript for publication, as required by the "Uniform requirements for manuscripts submitted to biomedical journals" (39).

Clinicians who are also researchers must be aware that their clinical relationship with the parent or child may provide undue coercion for participation. Arms-length consent procedures may reduce this risk (eg, a complex clinical trial is explained by an oncologist, but the final consent document is signed with a research associate not directly responsible for the clinical care of the child). Clinicians must honour their fiduciary responsibilities to the patient (where the patient's well-being comes first and foremost), regardless of how this may affect their research. They must also be careful to distinguish therapeutic interventions from those that are purely research, and to adopt for clinical practice only those that are found to be valid.

Researchers must also be cautious with respect to providing fair and reasonable compensation for participation in research, being attentive to the possibility that sums of money or gifts that are relatively insignificant to adults may be highly coercive to children (40). This same consideration should be brought to deliberations about the value of nonmonetary incentives.

\section{PROVISION OF RESEARCH RESULTS}

The offer of provision of research results to participants is increasingly recognized as an important obligation of researchers (41). There are benefits and risks to providing results; on one hand, the information may be directly useful to health care decisions, and on the other hand, results with adverse implications may cause individual distress. Health care providers should, in general, be made aware that a patient under their care is participating in research. With the parent's permission, paediatric health care providers should be prepared to receive relevant health care information about patients that is generated from the research and, sometimes in collaboration with the researcher, should formulate an interpretation and plan based on these results. Parents and participants should be made aware of the risks and benefits of receiving research results (summary or individual results), including the potential consequences of having sensitive research information documented in the health record.

While debate continues as to the scope of this obligation $(42,43)$, most researchers and research participants support the notion of offering to return relevant, informative results (44). The unique impact on children of offering results needs to be considered in research design. Questions that need to be considered include: 1) 'to whom should the results be provided if a parent has consented to the research with the child, but the child is now mature?'. Most would consider a summary of results in the public sphere and, thus, presentable to both the parent and now the mature child. However, individual health care results may be justifiably restricted to only the mature minor as private information. 2) Does reconsent need to occur in the case of biological tissues banked from children for future research? Respect for individuals suggests that this should occur, but has potential pitfalls with respect to retaining contact information. 3) What degree of validity is required for the provision of individual results? A number of researchers have clearly argued for a high degree of validity (some state that this should include confirmation in a clinical laboratory) before sharing health-related findings on which a participant might act $(45,46)$. These areas require continued discussion and empirical research to further delineate participant needs and outcomes.

\section{SPECIAL CONSIDERATIONS}

Some populations of children may be at special risk with respect to adequately informed consent, including those needing emergency care, those who are incarcerated or institutionalized, those participating in genetic or early phase drug research studies, socially disadvantaged children and children in international health research settings $(2,19,33,47-54)$. Some of these vulnerabilities stem from a child existing in a situation in which coercion and a lack of voluntariness may compromise assent and consent.

Aboriginal children (and adults) are specifically recognized in the TCPS as a population that requires special considerations in respecting community and cultural values. An additional complex issue is the ethical challenge engendered by the use of human tissues with respect to collection procedures, banking, maintenance of confidentiality and sharing of results.

Drug development in humans generally progresses through a number of phases. Phase I studies translate experimental models tested in tissue culture or animals to humans, and are primarily focused on establishing safety profiles and toxicity information of new drugs in patients with advanced disease for which there is no effective treatment. Phase II studies apply drugs in doses that are found to be reasonably safe to determine a preliminary assessment of potential efficacy and develop expanded toxicity profiles, again in patients with advanced disease. Both of these phases of study present a special challenge - the prospect of cure may be held out as hope in a fatal disease (55-57).

Those with life-threatening disease bring a number of risk factors that may unduly influence the adequacy of consent for research participation. Researchers must be particularly careful in understanding the motivations for participation in such research, and must provide accurate and realistic assessments for the potential for benefit to the individual child. Of course, some children are capable of understanding altruistic motives and should be allowed to participate in research for this aim.

Last, research conducted in international settings is an important obligation and component of Canadian scientific endeavours. Research conducted through Canadian institutions by Canadian researchers in other countries is required to undergo both Canadian REB review in the primary 
institution of the researcher and local review by the appropriate body in the country in which the research is being conducted. It is important to recognize that both Canadian and local national regulations apply to the researcher with respect to conduct, reporting and responsibilities. These regulations exist in both developed and developing countries $(10,12,34)$.

\section{RECOMMENDATIONS}

- Paediatric health care providers should advocate for research to be conducted in children based on a moral obligation of respect for persons in providing evidencebased care. This advocacy should extend to lobbying for adequate funding by public and private bodies, establishment of appropriate infrastructure, and assistance in practices that encourage the inclusion of children in the agendas of political, academic and scientific bodies.

- Paediatric health researchers should be aware of their obligations to conduct research according to the TCPS, including the need for REB review of applicable human research before its conduct. Those conducting research in Quebec should be aware of the provisions of article 21 of the Quebec Civil Code (11).

- Paediatric health researchers should recognize that children are developing autonomous decision-making capacity. Researchers should be attentive to including children in the discussion of consent for research participation. When full consent is not possible, assent should be appropriately sought from children and dissent carefully considered.

- Paediatric health researchers should be aware of potential COI in research endeavours related to dual roles as caregiver and researcher, as well as other COI rooted in potential financial or academic incentives.

\section{REFERENCES}

1. Neill SJ. Research with children: A critical review of the guidelines. J Child Health Care 2005;9:46-58.

2. Diekema DS. Conducting ethical research in pediatrics: A brief historical overview and review of pediatric regulations. J Pediatr 2006;149(Suppl):S3-11.

3. Caldwell PH, Murphy SB, Butow PN, Craig JC. Clinical trials in children. Lancet 2004;364:803-11.

4. Gericke CA, Riesberg A, Busse R. Ethical issues in funding orphan drug research and development. J Med Ethics 2005;31:164-8.

5. Gitterman DP, Greenwood RS, Kocis KC, Mayes BR, Mckethan AN. Did a rising tide lift all boats? The NIH budget and pediatric research portfolio. Health Aff (Millwood) 2004;23:113-24.

6. van Weely S, Leufkens HGM. Orphan diseases. Priority medicines for Europe and the world project. "A public health approach to innovation”. World Health Organization, Department of Essential Drugs and Medicines Policy. < http://mednet3.who.int/prioritymeds/ report/background/rare_diseases.doc $>$ (Version current at September 18, 2008).

7. Benjamin DK Jr, Smith PB, Murphy MD, et al. Peer-reviewed publication of clinical trials completed for pediatric exclusivity. JAMA 2006;296:1266-73.

8. Interagency Advisory Panel on Research Ethics (PRE). Tri-Council Policy Statement: Ethical conduct for research involving humans.
- Educational programs, such as residency programs and continuing medical education, should develop objectives and provide specific education for scholarship in research conduct.

- Paediatric health care providers should support the importance of scientific review in the conduct of highquality research. They should consider participating in REBs to provide a paediatric perspective to the review. REBs should have membership with expertise to adequately address the issues unique to paediatric research.

- Paediatric health researchers should strive to publish research results, whether negative or positive. They should aim to return a summary of the results to the community and to individual participants. When results have adequate reliability and validity with patient relevance, they should be offered to individual participants.

- Canadian researchers should participate in international health research and research in other socially vulnerable populations involving children. It is essential that students and researchers recognize the rights of participants in developing countries, including the obligation for Canadian and local REB review before the conduct of the research, the avoidance of exploitation of vulnerable populations, the care needed to reduce undue incentives, safety issues and responsibilities of the researcher after the research is completed.

ACKNOWLEDGEMENTS: The following groups reviewed the present position statement - Canadian Institutes of Health Research, the Paediatric Chairs of Canada, and the CPS Community Paediatrics, Drug Therapy and Hazardous Substances, and Fetus and Newborn Committees.

$<$ http://www.pre.ethics.gc.ca/english/policystatement/ policystatement.cfm > (Version current at September 18, 2008).

9. World Medical Association Declaration of Helsinki: Ethical principles for medical research involving human subjects. JAMA 2000;284:3043-5.

10. Council for International Organizations of Medical Sciences (CIOMS), World Health Organization (WHO). International ethical guidelines for biomedical research involving human subjects. $<$ http://www.cioms.ch/frame_guidelines nov_2002.htm > (Version current at September 18, 2008).

11. Government of Quebec. Civil Code of Quebec. Éditeur officiel du Québec. <http://www2.publicationsduquebec.gouv.qc.ca/ dynamicSearch/telecharge.php?type $=2 \&$ file $=/ C C Q / C C Q \_A . h t m l>$ (Version current at September 18, 2008).

12. Department of Health and Human Services, National Institutes of Health, Office of Human Subjects Research. Title 45. Code of Federal Regulations. Part 46. Protection of human subjects. Additional protections for children involved as subjects in research (Subpart D). <http://ohsr.od.nih.gov/guidelines/45cfr46.html> (Version current at September 18, 2008).

13. Weijer C. The ethical analysis of risk. J Law Med Ethics 2000;28:344-61.

14. American Society of Clinical Oncology policy statement: Oversight of clinical research. J Clin Oncol 2003;21:2377-86. 
15. Shah S, Whittle A, Wilfond B, Gensler G, Wendler D. How do institutional review boards apply the federal risk and benefit standards for pediatric research? JAMA 2004;291:476-82.

16. Emanuel EJ, Wood A, Fleischman A, et al. Oversight of human participants research: Identifying problems to evaluate reform proposals. Ann Intern Med 2004;141:282-91.

17. National Institutes of Health, Office of Human Subjects Research. The Belmont report: Ethical principles and guidelines for the protection of human subjects of research. <http://ohsr.od.nih.gov/ guidelines/belmont.html> (Version current at September 18, 2008).

18. Barfield RC, Church C. Informed consent in pediatric clinical trials. Curr Opin Pediatr 2005;17:20-4.

19. De Lourdes Levy M, Larcher V, Kurz R. Informed consent/assent in children. Statement of the Ethics Working Group of the Confederation of European Specialists in Paediatrics (CESP). Eur J Pediatr 2003;162:629-33.

20. Miller VA, Drotar D, Kodish E. Children's competence for assent and consent: A review of empirical findings. Ethics Behav 2004;14:255-95.

21. Fernandez CV. Context in shaping the ability of a child to assent to research. Am J Bioeth 2003;3:29-30.

22. Simon CM, Siminoff LA, Kodish ED, Burant C. Comparison of the informed consent process for randomized clinical trials in pediatric and adult oncology. J Clin Oncol 2004;22:2708-17.

23. Lidz CW. The therapeutic misconception and our models of competency and informed consent. Behav Sci Law 2006;24:535-46.

24. Angiolillo AL, Simon C, Kodish E, et al. Staged informed consent for a randomized clinical trial in childhood leukemia: Impact on the consent process. Pediatr Blood Cancer 2004:42:433-7.

25. Kodish E, Eder M, Noll RB, et al. Communication of randomization in childhood leukemia trials. JAMA 2004;291:470-5.

26. Miller VA, Drotar D, Burant C, Kodish E. Clinician-parent communication during informed consent for pediatric leukemia trials. J Pediatr Psychol 2005;30:219-29.

27. Kuther TL, Posada M. Children and adolescents' capacity to provide informed consent for participation in research. Adv Psychol Res 2004;32:163-73.

28. Kon AA. Assent in pediatric research. Pediatrics 2006;117:1806-10.

29. Joffe S, Fernandez CV, Pentz RD, et al. Involving children with cancer in decision-making about research participation. J Pediatr 2006;149:862-868.

30. Hurley JC, Underwood MK. Children's understanding of their research rights before and after debriefing: informed assent, confidentiality, and stopping participation. Child Dev 2002;73:132-43.

31. Tait AR, Voepel-Lewis T, Malviya S. Do they understand? (part II): Assent of children participating in clinical anesthesia and surgery research. Anesthesiology 2003;98:609-14.

32. Wendler DS. Assent in paediatric research: Theoretical and practical considerations. J Med Ethics 2006;32:229-34.

33. Gill D. Ethical principles and operational guidelines for good clinical practice in paediatric research. Recommendations of the Ethics Working Group of the Confederation of European Specialists in Paediatrics (CESP). Eur J Pediatr 2004;163:53-7.

34. Ethics Working Group of the Confederation of European Specialists in Pediatrics, Gill D, Crawley FP, et al. Guidelines for informed consent in biomedical research involving paediatric populations as research participants. Eur J Pediatr 2003;162:455-8.

35. American Society of Clinical Oncology. Revised conflict of interest policy. J Clin Oncol 2006;24:519-21.

36 Johns MM, Barnes M, Florencio PS. Restoring balance to industryacademia relationships in an era of institutional financial conflicts of interest: Promoting research while maintaining trust. JAMA 2003;289:741-6.
37. Lo B, Wolf LE, Berkeley A. Conflict-of-interest policies for investigators in clinical trials. N Engl J Med 2000;343:1616-20.

38. McCrary SV, Anderson CB, Jakovljevic J, et al. A national survey of policies on disclosure of conflicts of interest in biomedical research. N Engl J Med 2000;343:1621-6.

39. International Committee of Medical Journal Editors. Uniform requirements for manuscripts submitted to biomedical journals. $<$ www.icmje.org> (Version current at September 18, 2008).

40. Ramsey BW. Appropriate compensation of pediatric research participants: Thoughts from an Institute of Medicine committee report. J Pediatr 2006;149(1 Suppl):S15-9.

41. Fernandez CV, Kodish E, Weijer C. Informing study participants of research results: An ethical imperative. IRB 2003;25:12-9.

42. Markman M. Providing research participants with findings from completed cancer-related clinical trials: Not quite as simple as it sounds. Cancer 2006;106:1421-4.

43. Dixon-Woods M, Jackson C, Windridge KC, Kenyon S. Receiving a summary of the results of a trial: Qualitative study of participants' views. BMJ 2006;332:206-10.

44. Partridge AH, Winer EP. Informing clinical trial participants about study results. JAMA 2002;288:363-5.

45. Bookman EB, Langehorne AA, Eckfeldt JH, et al. Reporting genetic results in research studies: Summary and recommendations of an NHLBI working group. Am J Med Genet A 2006;140:1033-40.

46. Ravitsky V, Wilfond BS. Disclosing individual genetic results to research participants. Am J Bioeth 2006;6:8-17.

47. Agrawal M, Emanuel EJ. Ethics of phase 1 oncology studies: Reexamining the arguments and data. JAMA 2003;290:1075-82.

48. Geller G, Tambor ES, Bernhardt BA, Fraser G, Wissow LS. Informed consent for enrolling minors in genetic susceptibility research: A qualitative study of at-risk children's and parents' views about children's role in decision-making. J Adolesc Health 2003;32:260-71.

49. Kodish E, Stocking C, Ratain MJ, Kohrman A, Siegler M. Ethical issues in phase I oncology research: A comparison of investigators and institutional review board chairpersons. J Clin Oncol 1992;10:1810-6.

50. Nwomeh BC, Waller AL, Caniano DA, Kelleher KJ. Informed consent for emergency surgery in infants and children. J Pediatr Surg 2005;40:1320-5.

51. Weijer C, Goldsand G, Emanuel EJ. Protecting communities in research: Current guidelines and limits of extrapolation. Nat Genet 1999;23:275-80.

52. Arar NH, Hazuda H, Steinbach R, Arar MY, Abboud HE. Ethical issues associated with conducting genetic family studies of complex disease. Ann Epidemiol 2005;15:712-9.

53. Burke W, Diekema DS. Ethical issues arising from the participation of children in genetic research. J Pediatr 2006;149(Suppl):S34-8.

54. Knoppers BM, Joly Y, Simard J, Durocher F. The emergence of an ethical duty to disclose genetic research results: International perspectives. Eur J Hum Genet 2006;14:1170-8.

55. Anderson BD, Adamson PC, Weiner SL, McCabe MS, Smith MA. Tissue collection for correlative studies in childhood cancer clinical trials: Ethical considerations and special imperatives. J Clin Oncol 2004:22:4846-50.

56. Estlin EJ, Cotterill S, Pratt CB, Pearson AD, Bernstein M. Phase I trials in pediatric oncology: Perceptions of pediatricians from the United Kingdom Children's Cancer Study Group and the Pediatric Oncology Group. J Clin Oncol 2000;18:1900-5.

57. Kodish E. Pediatric ethics and early-phase childhood cancer research: Conflicted goals and the prospect of benefit. Account Res 2003;10:17-25.

\section{BIOETHICS COMMITTEE}

Members: Drs Susan Albersheim, BC Children's Hospital, Vancouver, British Columbia; Conrad Fernandez, IWK Health Centre, Halifax, Nova Scotia; Robert Hilliard, The Hospital for Sick Children, Toronto, Ontario; Saleem Razack, The Montreal Children's Hospital, Montreal, Quebec; Christina Templeton, Janeway Children's Health $E$ Rehabilitation Centre, St John's, Newfoundland (Board Representative); Ellen Tsai, Kingston General Hospital, Kingston, Ontario (Chair)

Principal author: Dr Conrad Fernandez, IWK Health Centre, Halifax, Nova Scotia

The recommendations in this statement do not indicate an exclusive course of treatment or procedure to be followed. Variations, taking into account individual circumstances, may be appropriate.

All Canadian Paediatric Society position statements/notes are reviewed, revised or retired as needed on a regular basis. Please consult the "Position Statements" section of the CPS website (www.cps.ca/english/publications/statementsindex.htm) for the current version. 